\title{
EFFECT OF AIR JET COOLING ON SURFACE ROUGHNESS AND TOOL WEAR
}

\author{
Paryanto, Rusnaldy, dan Tony S. Utomo \\ Department of Mechanical Engineering, Diponegoro University \\ Kampus Undip Tembalang, Semarang 50275, Indonesia \\ Email: paryanto@undip.ac.id
}

\begin{abstract}
The main goal of this work is to investigate the use of air jet cooling on machining process. Surface roughness and tool are chosen as parameter to analyze of air jet cooling effects; and turning process with AISI 1010 material used in the experimental study. Surface roughness was measured for several air jet pressures and in two air jet positions. Every five minutes of machining time, tool wear was measured until reach 30 minutes. Initial results show that the use of air jet cooling with proper selection of position and pressure; possible to reduce tool wear and to increase surface roughness.
\end{abstract}

Keyword: air jet cooling, cutting fluid,

\begin{abstract}
ABSTRAK
Tujuan dari penelitian ini adalah untuk mengetahui pengaruh penggunaan air jet cooling pada proses pemesinan. Kekasaran permukaan hasil pemesinan dan laju keausan pahat digunakan sebagai parameter yang diukur untuk menganalisis efektivitas penggunaan air jet cooling. Proses pemesinan yang digunakan dalam penelitian ini adalah proses bubut dengan material AISI 1010. Pengujian dilakukan pada beberapa kondisi tekanan udara dan arah penyemprotan. Pengukuran keausan pahat dilakukan setiap lima menit sekali sampai waktu pemesinan mencapai 30 menit. Hasil awal dari penelitian ini menujukkan bahwa penggunaan air jet cooling dengan pemilihan tekanan dan posisi penyemprotan tertentu dapat mengurangi laju keausan pahat dan meningkatkan kualitas kekasaran permukaan hasil pemesinan.
\end{abstract}

Kata kunci: air jet cooling, media pendingin, kekasaran permukaan, keausan pahat. 


\section{PENGANTAR}

Keausan pahat yang terjadi pada proses pemesinan merupakan sesuatu yang harus diminimalisasi karena akan menyebabkan terjadinya cacat pada hasil produk. Faktor terbesar penyebab terjadinya keausan pahat adalah karena adanya panas yang dihasilkan selama proses pemesinan (Bareggi, dkk., 2007). Sedangkan untuk meningkatkan produktifitas pemesinan dibutuhkan putaran spindel dan kecepatan potong yang tinggi. Hal ini jelas menghasilkan temperatur yang tinggi pada daerah pemotongan (Dhar, dkk, 2007). Oleh karena itu, diperlukan suatu cutting fluid (media pendingin) untuk mengurangi keausan pahat sehingga dapat meningkatkan kualitas hasil proses pemesinan.

Media pendingin yang digunakan sebagai pendinginan, pelumasan dan pembuangan geram akan menentukan performansi proses pemesinan (Çakīr, dkk., 2007; Iowa waste reduction center, 2003). Penggunaan media pendingin yang saat ini banyak dipakai masih mengandung zat-zat yang berbahaya bagi kesehatan operator dan tidak ramah lingkungan (Kauppinen, 2002; Jayal, dkk., 2007; Bareggi, dkk., 2006). Sehingga diperlukan alternatif media pendingin yang aman bagi kesehatan operator dan ramah lingkungan, tetapi efektif dalam penggunaannya. Salah satu solusi yang dapat diterapkan adalah dengan menggunakan pendingin udara bertekanan tinggi (Boswell \& Chandratilleke, 2009; Monno, dkk., 2006; Dahlman, 2001). Selain hal tersebut, dengan penggunaan udara sebagai media pendingin akan dapat mengurangi biaya operasional pada proses pemesinan (Feng \& Hattori, 2001).

Taylor melakukan penelitian tentang pengunaan air sebagai media pendingin pada pertengahan tahun 1890an, dari penelitian tersebut diperoleh kesimpulan bahwa pada pemesinan dengan kecepatan spindle yang tinggi, penggunaan media pendingin dapat memperpanjang umur pahat dan meningkatkan material removal rates (MRR). Meskipun demikian, pada perkembangan selanjutnya penggunaan media pendingin dalam proses pemesinan berusaha untuk diminimalisir, hal ini berkaitan dengan aspek ekonomi, ekologi, dan kesehatan manusia (Sales, dkk., 2001). Perkembangan pengunaan media pendingin pada proses pemesinan dapat dilihat pada Gambar 1.

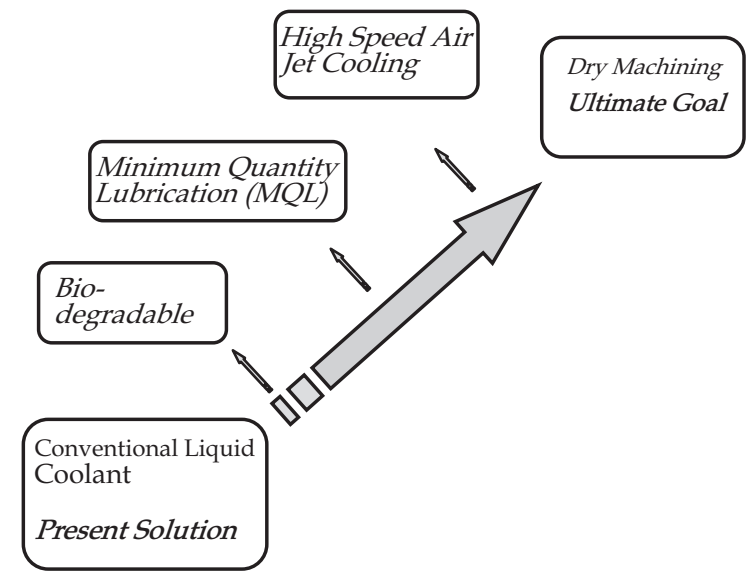

Gambar 1

Perkembangan penggunaan media pendinginan dalam proses pemesinan (Tonschoff, dkk., 1994).

Mulai tahun 1990an, proses pemesinan dengan menggunakan metode Minimum Quantity Lubrication (MQL) untuk berbagai jenis material telah mulai diteliti. Secara umum dari penelitian tentang MQL dapat disimpulkan bahwa dengan menggunakan MQL akan memberikan hasil yang lebih baik dibanding dengan pemesinan kering apabila ditinjau dari laju keausan pahat dan kekasaran permuka an hasil pemesinan (Kelly \& Cotterell, 2002; Weinert, dkk., 2004). Meskipun metode MQL memiliki banyak keuntungan dibandingkan dengan menggunakan media pendingin biasa, tetapi seiring dengan perkembangan industri, metodeinidianggapkurangefisienkarenamasih memerlukan fluid coolant sebagai campuran media pendingin sehingga tetap kurang ramah terhadap lingkungan dan menambah biaya proses pemesinan. Perkembangan terbaru tentang teknik pendinginan pada proses pemesinan adalah menggunakan air jet cooling karena pada metode ini tidak diperlukan lagi 
fluid coolant sehingga lebih ekonomis dan ramah lingkungan (Bareggi, dkk., 2006; Boswell \& Chandratilleke, 2009).

Su, dkk., (2006), melakukan penelitian tentang proses bubut dengan material Inconel 718 dengan menggunakan media pendingin udara yang didinginkan. Dalam penelitiannya proses pendinginan dilakukan dengan menyemprotkan udara dingin $\left(-20^{\circ} \mathrm{C}\right.$ sampai $\left.20^{\circ} \mathrm{C}\right)$ pada benda kerja dan pahat. Berdasarkan hasil penelitian ini, dibandingkan dengan pemesinan kering proses pendinginan metode ini mampu meningkatkan umur pahat dan meningkatkan kualitas permukaan benda kerja. Akan tetapi, pada proses ini memiliki kekurangan, yaitu diperlukannya suatu mekanisme tambahan yang digunakan untuk mendinginkan udara, sehingga tidak begitu efisien.

Perbandingan hasil pemesinan kering denganairjetcooling padamaterialbaja AISI1020 telah diteliti oleh Bareggia, dkk., (2007) dengan menggunakan pemodelan finite element method (FEM). Pada penelitian tersebut diperoleh kesimpulan bahwa dengan menggunakan tekanan dan posisi penyemprotan udara yang tepat dapat menurunkan temperatur pahat, sehingga dapat mengurangi keausan yang terjadi pada pahat.

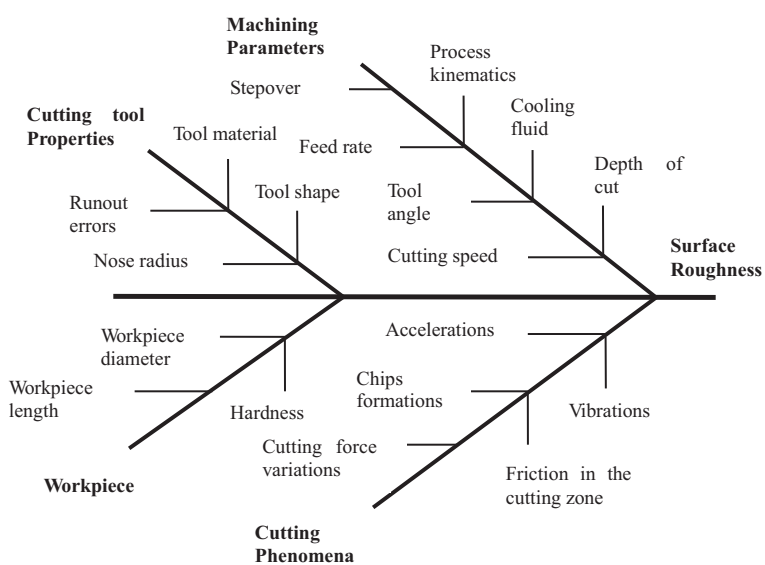

Gambar 2

Diagram fishbone faktor-faktor yang berpengaruh terhadap kekasaran permukaan (Benardos \& Vosniakos, 2003; Salgado, dkk., 2008).
Boswell dan Chandratilleke (2009) dalam penelitiannya mengenai proses pemesinan dengan pendinginan menggunakan udaradingin menyimpulkan bahwa udara-dingin dapat meminimalisasi keausan pahat. Penelitian tentang efektifitas dari penggunaan media udara sebagai pendingin pada proses pemesinan sampai saat ini masih terus dilakukan. Menurut Benardos \& Vosniakos (2003) dan Salgado, dkk (2008), secara umum kekasaran permukaan suatu benda kerja hasil proses pemesinan dipengaruhi oleh berbagai faktor, seperti parameter proses pemesinan, kondisi pahat, benda kerja dan fenomena pemotongan (Gambar 2). Berdasarkan kondisi tersebut, maka masih diperlukan suatu penelitian yang dapat mengukur efek dari penggunaan air jet cooling terhadap laju keausan pahat dan kekasaran permukaan hasil proses pemesinan.

Tujuan dari penelitian ini adalah untuk mengukur laju keausan pahat dan kekasaran permukaan hasil proses pemesinan menggunakan pendinginan air jet cooling. Dari data tersebut akan diperoleh besarnya tekanan dan posisi penyemprotan yang optimum sehingga diperoleh laju keausan pahat dan kekasaran permukaan yang minimum.

\section{Metodologi Penelitian}

Pada penelitian ini, metode yang digunakan untuk menganalisis efek air jet cooling pada proses pemesinan adalah dengan cara ekperimental dan simulasi numerik. Tetapi pada makalah ini, hanya dijabarkan hasil dari pengujian secara eksperimental, sedangkan hasil simulasi dapat dilihat di referensi Paryanto, dkk., 2010.

\subsection{Material Penelitian}

Benda kerja yang digunakan dalam penelitian ini adalah AISI 1010 dengan dimensi $\varnothing 34 \times 60 \mathrm{~mm}$. Komposisi unsur kimia sepesimen uji adalah sebagai berikut: $\% \mathrm{C}=$ 0,$10 ; \% \mathrm{Si}=0,21 ; \% \mathrm{Mn}=0,66 ; \% \mathrm{Ni}=0,11 ; \% \mathrm{Fe}$ = 98,12; dengan nilai kekerasan 55,7 HRA. 
Pemilihan material AISI 1010 didasarkan karena bahan tersebut sering dipakai oleh bengkel-bengkel permesinan di Indonesia sebagai bahan baku pembuatan komponen mesin. Sebelum digunakan sebagai spesimen uji benda kerja telah difacing terlebih dahulu dengan kedalaman 2 mm dengan tujuan untuk membuang permukaan benda kerja yang mengalami pengerasan akibat pengerolan selama proses manufaktur. Jenis pahat yang digunakan adalah TNMG 160404 FG CT 3000 dengan tool holder tipe PTNFR1616.

\subsection{Peralatan Penelitian}

Mesin bubut yang digunakan adalah EMCO Maier Maximat V13. Media pendingin yang digunakan adalah udara bertekanan yang dihasilkan oleh kompresor dengan kemampuan menghasilkan udara diatas 6 bar pada kondisi semua katup terbuka. Untuk mengetahui kekasaran permukaan benda kerja yang dihasilkan dari proses permesinan digunakan Mitutoyo Surftest SJ-201P roughness tester. Termometer KW06283 digunakan untuk mengukur temperatur pahat pada waktu proses pemesinan. Pada termometer jenis ini dilengkapi dengan thermocouple yang digunakan sebagai sensor yang ditempelkan dibenda yang akan diukur. Gambar 3 memperlihatkan posisi pemasangan thermocouple pada pahat. Pengukuran temperatur dimaksudkan untuk mengetahui hubungan antara temperatur pemotongan dengan laju keausan pahat.

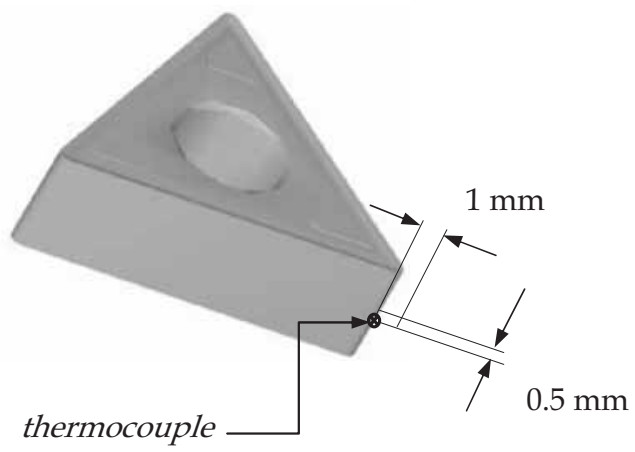

Gambar 3

Posisi pemasangan thermocouple.

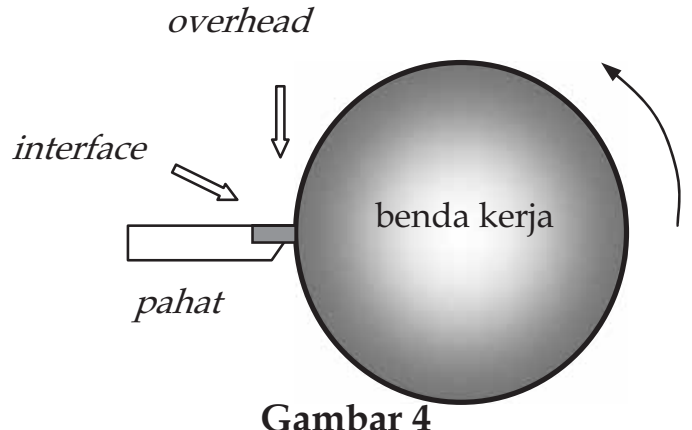

Posisi penyemprotan udara pendingin.

\subsection{Sistem Pengujian}

Pengujian dilakukan dengan menvariasikan tekanan penyemprotan dari 0,5-6 bar, masingmasing untuk posisi interface dan overhead (Gambar 4). Sedangkan sistem pengujian terlihat seperti Gambar 5. Pengujian dilakukan untuk proses finishing, dengan kecepatan potong 140 $\mathrm{m} / \mathrm{min}$, kedalaman potong $0,5 \mathrm{~mm}$ dengan feed 0,112 mm/rev. Parameter pengujian secara keseluruhan diperlihatkan seperti terlihat pada Tabel 1.

Tabel 1

Parameter proses pengujian.

\begin{tabular}{ll}
\hline Parameter pengujian & Nilai \\
\hline Jenis media pendingin & $\begin{array}{l}\text { dry, wet }(32,7 \mathrm{l} / \mathrm{h}), \\
\text { air jet cooling }(0,5-6 \mathrm{bar})\end{array}$ \\
Kecepatan potong $\left(v_{c}\right)$ & $140 \mathrm{~m} / \mathrm{min}$ \\
Feed $(f)$ & $0,112 \mathrm{~mm} / \mathrm{rev}$ \\
Kedalaman potong $(a)$ & $0,5 \mathrm{~mm}$ \\
Diameter nozzel $(d)$ & $2 \mathrm{~mm}$ \\
Jarak ujung nozel dengan geram & $2 \mathrm{~cm}$ \\
\hline
\end{tabular}

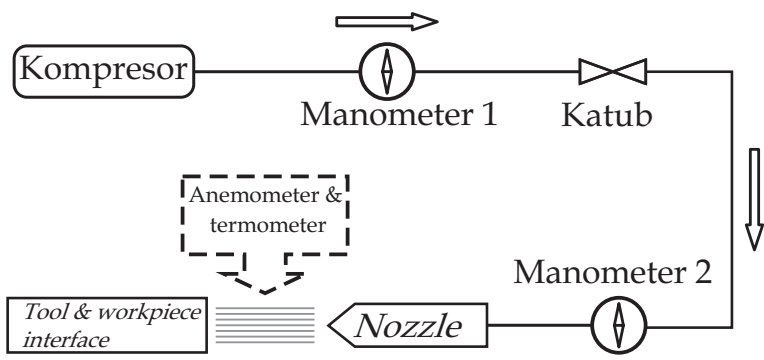

Gambar 5

Skema sistem pengujian. 


\section{PEMBAHASAN}

Pemesinan ramah lingkungan merupakan tujuan dari proses manufaktur dimasa yang akan datang. Salah satu cara yang dilakukan untuk penerapan teknologi ramah lingkungan adalah pengunaan air jet cooling. Pengurangan biaya produksi dan adanya peraturan dari pemerintah merupakan dua hal yang melatarbelakangi pengunaan teknologi air jet cooling.

\subsection{Kekasaran Permukaan Hasil Pemesinan}

Setelah dilakukan proses pemesinan, benda kerja hasil pengujian dilakukan pengukuran kekasaran permukaan. Berdasarkan hasil pengukuran kekasaran, diperoleh dapat data seperti terlihat pada Gambar 6. Secara umum penggunaan air jet cooling mampu menurunkan nilai kekasaran permukaan hasil proses pembubutan. Hal ini terlihat dari perbandingan antara kekasaran permukaan hasil pemesinan kering (dry) dengan kekasaran permukaan hasil pemesinan menggunakan air jet cooling. Peningkatan kualitas permukaan ini disebabkan karena dengan pendinginan air jet cooling pahat mengalami proses pendinginan sehingga mengurangi kemungkinan adanya geram yang terdifusi dengan pahat, yang dapat mengubah geometri pahat sehingga menurunkan kualitas hasil proses pembubutan. Selain hal tersebut, dengan adanya pendinginan air jet cooling juga dapat membuang geram yang terbentuk sehingga tidak merusak permukaan benda hasil proses pembubutan.

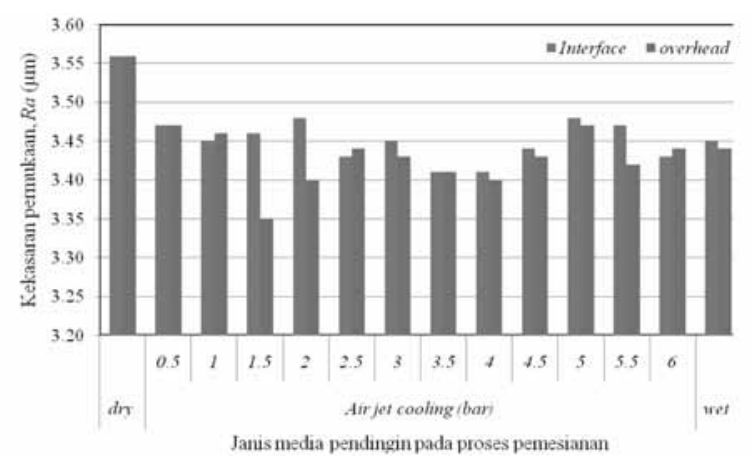

Gambar 6

Kekasaran permukaan hasil proses pemesinan.
Hasil pemesinan dengan air jet cooling juga mampu menyamai dengan hasil pemesinan basah (wet), bahkan pada tekanan penyemprotan 3,5 bar dan 4 bar diperoleh kekasaran permukaan yang lebih baik dibandingkan dengan pemesinan basah. Sehingga apabila mengacu pada proses pemesinan yang ramah lingkungan (green machining/eco-machining) dan efisiensi proses pemesinan, penggunaan air jet cooling lebih menguntungkan jika dibandingkan dengan pemesinan basah.

\subsection{Laju Keausan Pahat}

Sebagian besar energi yang digunakan untuk proses pemotongan logam diubah menjadi panas, kemudian panas ini akan diteruskan ke geram, pahat, dan benda kerja. Dari proses perpindahan panas tersebut maka akan menyebabkan terbentuknya tiga daerah panas, yaitu: daerah panas pada bidang geser, daerah panas pada kontak antara geram dan permukaan pahat, dan daerah panas pada kontak antara permukaan pahat dan benda kerja. Distribusi temperatur pemotongan pada proses pemesinan perlu untuk diketahui, hal ini karena dengan mengetahui distribusi temperatur pemotongan akan dapat diketahui laju keausan pahat. Dari hasil pengukuran temperatur pahat diperoleh grafik seperti pada Gambar 7.

Dari Gambar 7 diketahui bahwa tekanan penyemprotan semakin dinaikkan maka pendinginan terhadap pahat akan semakin efektif, tetapi apabila tekanan dinaikkan melebihi 3 bar maka pendinginan pahat menjadi tidak begitu efektif. Hal ini karena pada tekanan rendah, laju dari aliran udara pendingin belum menghasilkan pendinginan yang cukup untuk membuang panas yang dihasilkan selama proses pemotongan. Khusus untuk posisi interface tekanan tersebut belum cukup untuk masuk ke celah antara pahat dan benda kerja. Jika tekanan penyemprotan melebihi 3 bar, maka efektivitas pendinginan akan semakin berkurang, hal ini karena pada tekanan diatas 3 bar udara pendingin 
mengalami kompresi yang menyebabkan naiknya temperatur udara pendingin dan tumbukan antara udara yang disemprotkan dengan benda kerja/pahat menyebabkan panas, sehingga pendinginan tidak begitu efektif.

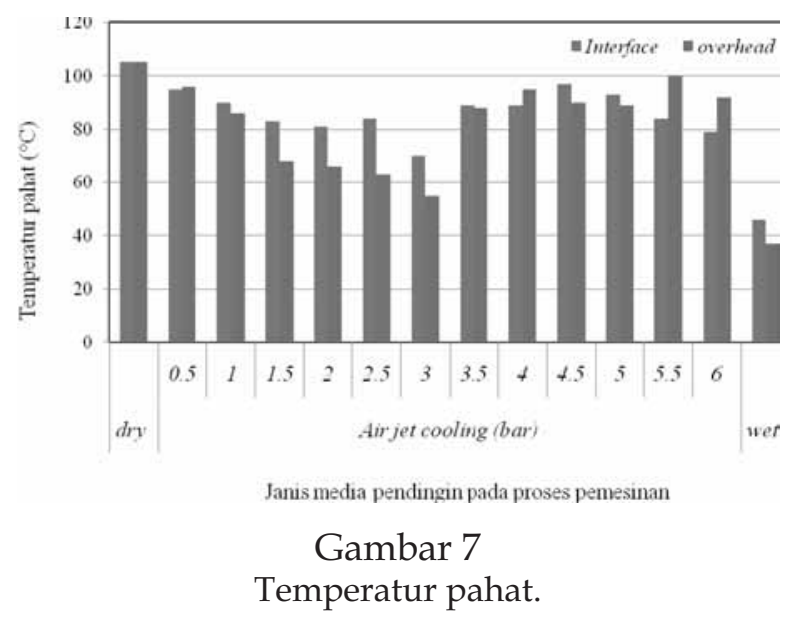

Pendinginan menggunakan air jet cooling paling efektif mendinginkan pahat adalah pada tekanan penyemprotan 3 bar, hal tersebut terjadi baik pada posisi interface maupun pada posisi overhead. Secara umum, jika ditinjau dari kemampuan pendinginan terhadap pahat maka pendinginnan dari arah overhead lebih baik jika dibandingkan dengan pendinginan dari arah interface.

Dari pengujian keausan pahat yang telah dilakukan diperoleh grafik keausan tepi maksimum pahat seperti terlihat pada Gambar 8. Pada pengujian tersebut pendinginan air jet cooling dilakukan pada tekanan penyemprotan 3 bar dengan posisi dari arah overhead. Dari grafik terlihat bahwa penggunaan air jet cooling secara umum mampu mengurangi laju keausan pahat jika dibandingkan dengan proses pemesinan kering. Hal ini karena dengan menggunakan air jet cooling pahat megalami proses pendinginan sehingga temperatur pahat tidak terlalu tinggi. Temperatur pahat yang tinggi akan menurunkan kekuatan material pahat dan memfasilitasi terjadinya fenomena abrasi dan difusi. Akibat kekuatan material yang menurun, adanya abrasi dan adanya fenomena difusi akan menyebabkan pahat menjadi mudah aus.

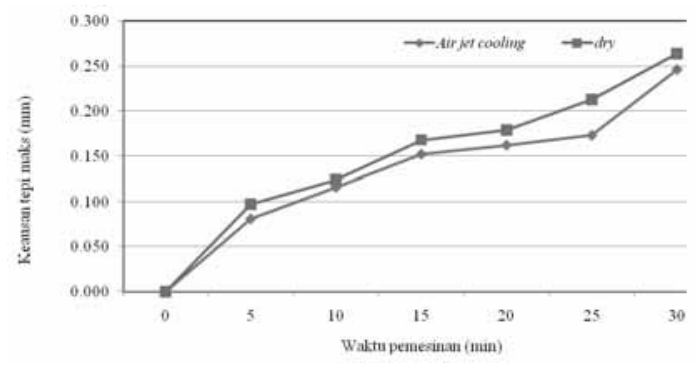

Gambar 8

Laju keausan tepi pahat.

\section{SIMPULAN}

1) Jika ditinjau dari nilai kekasaran permukaan, pemesinan dengan air jet cooling akan lebih baik jika dibandingkan dengan pemesinan kering.

2) Dengan menggunakan air jet cooling akan dapat mengurangi temperatur pemotongan sehingga mampu untuk mengurangi laju keausan pahat.

3) Pada tekanan penyemprotan 3 bar dengan posisi penyemprotan overhead diperoleh nilai optimum dengan efek pendinginan yang paling efektif.

4) Secara umum, apabila mengacu pada proses pemesinan yang ramah lingkungan (green machining/ecomachining) maka penggunaan air jet cooling lebih menguntungkan jika dibandingkan dengan pemesinan basah.

\section{DAFTAR PUSTAKA}

Bareggi, A., Torrance, A., O' Donnell, G., (2006), "Green cutting using supersonic ait jets as coolant and lubricant during turning", Advanced in Manufacturing Technology, 261 - 266.

Bareggi, A., Torrance, A., O' Donnell, G. (2007), "Modelling thermal effects in machining by finiteelement method"., Proceedings of the $24^{\text {th }}$ International Manufacturing Conference, Waterford, $263-272$. 
Benardos, P.G., Vosniakos, G.C., (2003), "Predicting surface roughness in machining: a review", International Journal of Machine Tools $\mathcal{E}$ Manufacture $43,833-844$.

Boswell, B., Chandratilleke, T.T., (2009), "Air-cooling used for metal cutting", American Journal of Applied Sciences 6 (2), 251 - 262.

Çakīr, O., Yardimeden, A., Ozben, T., Kilickap, E., (2007), "Selection of cutting fluids in machining processes"., Journal of Achievements in Materials and Manufacturing Engineering 25, 99 - 102.

Dahlman, P., (2001)., “A comparison of temperature reduction in high-pressure jet-assisted turning using high pressure versus high flowrate", Master's thesis, Production Engineering, Chalmers University of Technology, Sweden.

Dhar, N.R., Islam, S., Kamruzzaman, M., (2007), "Effect of minimum qantity lubrication (MQL) on tool wear, surface roughness and dimensional deviation in turning AISI-4340 steel"., G.U. Journal of Science 20 (2), 23 - 32.

Feng, S.C., Hattori, M., (2001), “Cost and process information modeling for dry machining", Manufacturing Engineering Laboratory, NIST DoC.

Iowa Waste Reduction Center, (2003), Fluid cutting management for small machining operations, a practical pollution prevention guide $3^{r d}$ edition, University of Northern Iowa.

Jayal, A.D., Balaji, A.K., Sesek, R., Gaul, A., Liliquist, D.R., (2007), "Machining performance and health effect of cutting fluid application in drilling of A390.0 cast aluminium alloy", Journal of Manufacturing Processes, 9 (2), 137 - 146.

Kauppinen, V., (2002), “Environmentally reducing of coolants in metal cutting", Proceedings University's Days $8^{\text {th }}$ International Conference, Helsinki University of Technology.

Kelly, J.F., Cotterell, M.G., (2002), “Minimal lubrication machining of aluminium alloys", Journal of Materials Processing Technology 120, 327 - 334.

Monno, M., Pittala, G.M., Bareggi, A., (2006), "Finite element modeling of titanium assisted by high speed air jet", Politecnico di Milano, Dipartimento di Ingegneria Meccanica.

Paryanto, Rusnaldy, T.S. Utomo and Y. Umardani, (2010), “Aplikasi penggunaan air jet cooling pada proses pemesianan", Proceeding of TEKNOIN National Conference: Green Technology, Yogyakarta, E 91 - 98.

Sales, W.F., Diniz, A.E., Machado, A.R., (2001), "Application of cuttingfluidsinmachining processes", Journal of the Brazilian Society of Mechanical Sciences, 23 (2).

Salgado, D.R., Alonso, F.J., Cambero, I., Marcelo, A., (2009), "In-process surface roughness prediction system using cutting vibrations in turning", International Journal of Advance Manufacturing Technology 43, 40 - 51.

$\mathrm{Su}$, Y., He, H., Li, L., Iqbal, A., Xiao, M.H., Xu, S., Qiu, B.G., (2007), "Refrigerated cooling air cutting of difficult-to-cut materials", International Journal of Machine Tools $\mathcal{E}$ Manufacture 47, 927 - 933.

Tonschoff, H.K., Kroos, F., Sprinting, W., Brandt, D., (1994), "Reducing use of coolant in cutting cutting processes", Production Engineering 1 (2), 5 - 8.

Weinert, K., Inasaki, I., Sutherland, J.W., Wakabayashi, T., (2004), "Dry machining and minimum quantity lubriction". Dept. of Machining Technology, University of Dortmund, Germany. 